\title{
The situation and Strategy to Promote the Quality of University Students' Employment
}

\author{
Guang Li \\ Baoshan University, Baoshan, 678000, China
}

Keywords: Promote; University students' employment quality, The status quo; Strategy

\begin{abstract}
In the process of leap-forward development of higher education, college students' human resources increasingly fierce market competition, the employment situation of college students is relatively serious; it has become one of the most difficulties in employment in our country. Moreover, college students employment quality, has appeared serious problem, caused a certain influence on our country's economy development. How to promote the quality of university students' employment has become the inevitable choice of education department and the department of university employment work. Through the analysis of the realistic predicament of university students' employment quality, we will put forward corresponding measures to promote, continue to promote sound and rapid development of economy.
\end{abstract}

\section{Introduction}

Employment Quality is by the vocational training and development committee in 1970 "the Quality of work Life" - Quality of work Life. Although the research has achieved continuous development, but there is no generally accepted concept. Generally understood as: laborer is in Free state, the currently engaged in the professional satisfaction degree, and it is good for the future career development degrees ${ }^{[1]}$..

It can be understood as the first employment for university students' employment quality of college students on their personality characteristics and professional skills and practical ability of the comprehensive consideration, and the overall satisfaction of work to do.

Quality has fallen into the employment rate of graduates and employment trends, from $93.7 \%$ in 1996 to $40 \%$ by 2009. Today, college students' employment has become a serious social problem generally, to the society, college graduates, family, and caused great pressure, such as to government departments at all levels of work put forward severe challenges.

\section{The significance of university students' employment quality}

\section{Affect the social stability and development}

Because a single college campus life environment, access to narrow the social comparison, the students are not familiar with the situation of the development of the society. Employment quality is low, that will influence the cultivation of college students' personality, which have a negative impact on social stability. Employment is about people's livelihood, the employment of college students quality will influence the individuals, families, and extended to the whole society ${ }^{[2]}$. Low quality of the employment of college students, make students have a lot of loss, a huge gap between ideals and the reality, and it may lead to the extreme antisocial, against humanity thought, brought a lot of disadvantage of hidden danger for the society.

\section{Affect the healthy development of market economy}

College students have played a very important role in the country's economic development, to the health of the market economy and the development of scientific and reasonable to make their own contribution. Due to the labor market in our country, through the influence of multiple factors, has been split into two extreme markets, namely, a senior Labor and lower the Labor market. University talent market system still exists many loopholes, caused many college students flocked to the senior laborer market, led to the oversupply of, make the configuration of human resources has not been 
optimized, college students' human resources consumed, hindered the sustainable and healthy development of the economy.

\section{Affect the healthy development of the cause of higher education in our country}

College students as a symbol of China's higher education, which represents is the power of our education system, the quality of their employment status, they make the people to trust suspicion of education in our country, the public is not willing to the consequences of education investment, which affected the healthy development of the education of our country. For a long time in the past, will be the development of the whole national economy in China caused irreparable damage.

\section{To promote the quality of university students' employment situation}

\section{College students' own problems}

Not right positioning

Today's college students, in the process of the whole school education come into contact with the social lighter, almost no social experience. They are accompanied by her parents, teachers, classmates, grow up, the lack of independent life experience, understanding of their own don't have a clear and accurate positioning. In the process of employment, often appear "traffic jam" phenomenon, intensified competition. Some people have no jobs, some jobs no one is a true portrayal. In addition, the college students in employment, focusing on salary, working environment, benefits and development, etc., the lack of their own career planning, to ignore the prospect of career development, into a dead end, often appear "down" phenomenon.

\section{Concept of bondage}

People always have a solid potential thinking: state-owned enterprises, government departments and institutions, can provide a good working environment and welfare system, but the wages and employment prospects, and private enterprise can provide high salary, but work is not stable. College students in the post when the choice, flocked to state-owned enterprises, government departments and institutions, and for the private enterprise of high strength work, and fast-paced life, treatment of unstable, usually untouched ${ }^{[3]}$. Appear this kind of situation the main reason is that college students are under the yoke of employment concept, not challenging, lack of a sense of momentum and struggle.

The quality level is low

Now the "labor shortage", "employment" phenomenon is not without its inevitability. Many enterprises are calling, " where are the talents?" Sigh with emotion, and the college students is "serve slam shut." The generation of this paradox is the result of comprehensive shaping of many factors, the enterprise needs to practice, efficient, innovative talents, whereas the undergraduate is zero experience, pure, light practice of scholar. Many college students have grandiose, a lack of jobs required quality and comprehensive ability, hard work positions. At the same time, many college students are overconfidence, the goal is too high, aim high, they have yet to master the basic knowledge and skills, not the right attitude, motivation is not pure factor, it is difficult to win the favor of unit of choose and employ persons. After repeated job search setback, a lot of college students but chose a low-level jobs, their satisfaction will decrease, affect the quality of the university students' employment.

\section{Employment threshold is too high.}

Many of companies choose and employ persons set higher work conditions and requirements, strict, the assessment of the comprehensive quality of college students and even many discriminatory violating laws and regulations, policies, human caused some employment difficulties. Lowered the self-confidence of students to employment, affect the quality of the university students' employment. In addition, the majority of unit of choose and employ persons in the selection of personnel, tend to select has the work experience. College students into the enterprise, most have to grope for, not set the mode of talent cultivation, the decrease of the job satisfaction of the students. 


\section{School education confusion}

Personnel training mode of higher education in our country, most follow outdated curriculum, and the talent training plan, of course update do not reach the designated position. The knowledge which students study in school is old, hard to use. At the same time, the training mode of education, the cultivation of lay particular stress on theoretical knowledge, ignore the cultivation of students' practice ability. Education way is old and did not keep pace with The Times to apply the latest technology, makes the accustomed to the information age of high technology College students cannot adapt to the traditional teaching method. In addition, the college education and employment contact close enough, ignoring the cultivation of students' employment ability, it is difficult to make students employment fundamentally improve the quality in the future.

\section{Employment policy to promote the quality of university students}

\section{Promote college students' employment ability}

Employment ability is an expression of the comprehensive quality of college students, both in professional quality, skills, and theory of appraisal, it also involves the physical quality, cultural quality, and other comprehensive quality inspection. The emphasis of the university education is a professional education, which ignore the development of the students' comprehensive quality and to develop, it should clearly put forward in the new talent training scheme in the really implement and track to cultivate all-round development of students' quality, achieve the goal of optimizing students' knowledge structure.

To cultivate college students' employment ability is determined by social work. Therefore, there should be enterprise and school, common to set the aim of training students. On the personnel training mode, adhere to market-oriented, for the future as well as globally. It can through the university-enterprise cooperation, carries on the cultivation of talents.

Each college education management can be managed for the cultivation of the innovative ability of students, management innovation, and management innovation and interaction mechanism with enterprise employment. Through management innovation, it is to realize the integration of college and university and enterprise management goal, improve the quality of the students' employment. In addition, the severe employment situation, university can choose to have another way that entrepreneurship. Therefore, university education should be increased entrepreneurship education module, guides the student to the innovation of the career choice. The entrepreneurship education of colleges and universities can use using the professional guidance of science and technology, the integration of the model between teachers and students can be used. Entrepreneurship education in colleges and universities, concrete implementation, should also be reflected in the entrepreneurship education curriculum education and practice arrangement.

\section{To improve college students' employment service}

The government's employment of students is playing an important leading role. In order to improve the quality of the students' employment, the government can by means of macro policy, policy of college students' employment guidance, through to the human resources reasonable calls, configuration, to achieve the balance of supply and demand in talent market. In addition, the government should strengthen the labor market to strengthen control and management, strictly related legal policy, reasonable penalties on the phenomenon of employment discrimination, and create a good employment environment. The government should improve the quality of employment service, establishing perfect employment service system, provide a lot of jobs, increase the employment of college students, finishing to improve the quality of university students' employment.

\section{Guide students to establish correct concept of employment}

Because of the college students on employment problem hesitate, easily affected by external factors. And errors are greatly will largely affect the job satisfaction degree of college students, which affect the improvement of college students' employment quality ${ }^{[4]}$. Therefore, colleges and universities should increase in the education career planning and employment education content, to guide college students' right are greatly set, let the students to be able to enter the social employment 
situation to be a basic understanding of, and for their ability to have a more clear understanding, as well as the ability to choose suitable for their jobs.

\section{Improve the labor and social security system, improve the labor relations.}

The college students employment quality and employment unit provided directly contacted with the salary, labor and social security. Unit of choose and employ persons should strictly implement the relevant laws and regulations of national labor law, improve the labor and social security system, and to improve the relationship between workers and improve their competitiveness, and workers to achieve win-win and mutually beneficial win-win situation. Companies of choose and employ persons should build good employment prospects and career development channels, increase the employment of college students, improve the quality of college students' employment.

\section{Promote the transformation combination and production personnel training mode}

The school according to the market need, they will do the transition of the talent training. With the combination of social enterprises, the latest development of the society for talents demand reflected in the process of education in colleges and universities. At the same time, through the practice of social enterprises, which in turn inspection, consolidate and update the knowledge learned in school, develop more conforming to the latest development and society's most urgent need of the society. Enterprise contact campus, not only should reflect on the education target, they should go deep into the classroom, the enterprise in the field of high-level personnel in colleges and universities set up professional classroom, introduce the latest technology application, looking forward to the future of the social development direction, thus for students to contact the social cognitive approach for professional field, and make students establish the correct self-cognition and greatly. In addition, the enterprise can make use of campus resources, to carry on the project cooperation, let the students to follow up the whole project process, thus the application of professional knowledge has a more in-depth understanding.

\section{Implementation of credit system, optimize the curriculum}

Colleges should keep up with the pace of reform of higher education; fully learn accord with the actual situation of our outstanding teaching and management experience.

First, implement credit system. In the process of implementation of credit system, academic elastic system and allow the existence of the system of professional and re-election. Flexible length allows students midway employment within the prescribed time limit or suspend the employment, to continue learning or training. Professional reelection is primarily aimed at students blindly choose major in the college entrance examination, do not understand professional, to learn, not love of underemployed.

Second, slow professional segmentation process. When new students go school, many professional already qualified, also in strict accordance with the requirements set up complete course. In professional, subject, under the condition of course do not understand, a lot of students have to learn which they don't want to learn, and cannot learn what they want to learn, it is easy to cause learning motivation and efficiency is low, and even drop out of school. As a result, it can consider to give students to choose the time, delay the shunt of professional, let the students according to their own interest to choose professional and part of the course.

Third, to optimize the curriculum. Many problems will exist in the course of colleges and universities, the rigidity of the curriculum and it is difficult to adapt to the society, unit of choose and employ persons and the needs of students; Elective system inflexible; Number of courses, course selection; Lack of autonomous learning and inquiry learning in the process of teaching, etc., which are against the cultivation of students' comprehensive ability. Therefore, to balance the various needs, set up corresponding courses, these courses to fully embody the force to cultivate the students' employment goals. Can also through professional employment guidance course, interpersonal and instrument etiquette lecture, quality development, job evaluation, simulation recruitment, mental health education, career planning and design, campus cultural activities, etc., to improve students' employment. 


\section{Conclusion}

Employment problem is related to people's livelihood, it should get attention, and the problem of employment of college students is one of the most notable. Because of the college students' employment quality, has a significant impact on the whole society and country. So, college students' employment quality is an important index of a test of a harmonious society, and is related to the healthy development of social economy. Therefore, to improve the quality of university students' employment, should by the state, social and school three aspects, work together to play their part, respectively, and to strengthen the theory and practice of college students employment quality research.

\section{References}

[1] Ge Li. Under the employment competition force as Fu Jian. Journal of entrepreneurship education in colleges and universities pattern innovation education development research, 2011 (12): 75-77.

[2] He Zhenxiong. Integrating different postgraduate training mode to meet the needs of social development for all kinds of talents. Journal of degree and graduate education

[3] Liu Guihua. The British enlightenment of the college students' employability training Education and career, 2010 (16) : 98-99.

[4] Ma Hongliang, Wang Jing. College students' career development and employment guidance curriculum implementation of the empirical study. Journal of college counselors, 2011 (3), 62-66.

[5] Zhu Shengyu, Chen chen. The analysis of the causes of college graduates' employment and countermeasures study. Journal of heilongjiang education (higher education research and evaluation), 2009 (9). 